\title{
Optimizing the growth-associated $\beta$-galactosidase production by probiotic Lactobacillus reuteri B-14171: experimental design, culture medium volume increase, and cell growth modeling
}

Otimização da produção de $\beta$-galactosidase associada ao crescimento por Lactobacillus reuteri B14-171 probiótica: delineamento experimental, aumento de volume do meio de cultivo e modelagem de crescimento celular

\author{
T. A. Gomes ${ }^{1 *}$; É. Fontana ${ }^{2}$; A. A. F. Zielinski³ ; A. Nogueira ${ }^{4}$; M. R. Spier ${ }^{1}$ \\ ${ }^{1}$ Food Engineering Postgraduate Program, Department of Chemical Engineering, Federal University of Paraná \\ (UFPR), 81530-900, Curitiba-Paraná, Brazil \\ ${ }^{2}$ Department of Chemical Engineering, Federal University of Paraná (UFPR), 81530-900, Curitiba-Paraná, Brazil \\ ${ }^{3}$ Department of Chemical Engineering and Food Engineering, Federal University of Santa Catarina (UFSC), 8040- \\ 970, Florianópolis-Santa Catarina, Brazil \\ ${ }^{4}$ Graduate Program in Food Science and Technology, State University of Ponta Grossa (UEPG), 84030-900, Ponta \\ Grossa-Paraná, Brazil
}

*tatianeapgomes@gmail.com

(Recebido em 17 de dezembro de 2020; aceito em 01 de abril de 2021)

\begin{abstract}
This study reports an optimized culture medium in submerged cultivation to produce $\beta$-galactosidase by Lactobacillus reuteri. Four culture medium parameters were optimized $(\mathrm{pH}$, lactose, casein, and inactive beer yeast), and the effect of different volumes of the optimized culture medium on the bioprocess was evaluated regarding $\beta$-galactosidase production. Different kinetic models were applied to predict enzymatic production as a function of biomass and substrate. It is the first time that both the effect of increasing the culture medium volume and mathematical modeling on the $\beta$-galactosidase production by $L$. reuteri have been studied. Besides, different bioprocess parameters were calculated based on the experimental data to verify the feasibility of enzymatic production. The achieved enzymatic activity for the optimized culture medium (12.75 $\mathrm{g} \mathrm{L}^{-1}$ lactose; $1.88 \mathrm{~g} \mathrm{~L}^{-1}$ casein; $1.65 \mathrm{~g} \mathrm{~L}^{-1}$ inactive beer yeast and $\mathrm{pH}$ 5.61) resulted in an increase of 4.74fold compared to the initial activity. Three culture medium volumes $(200,800$, and $3,200 \mathrm{~mL})$ were evaluated, and no significant difference was observed on maximum and total productivities $\left(\mathrm{P}_{\mathrm{m}}\right.$ and $\left.\mathrm{P}_{\mathrm{p}}\right)$, as well as on the product formation yield on biomass $\left(\mathrm{Y}_{\mathrm{P} / \mathrm{X}}\right)$. The Logistic model resulted in a good fit to the experimental data for all tested volumes, and the modified Luedeking-Piret model provided a satisfactory prediction of the enzymatic activity. The optimized culture medium reported in this work is an outstanding alternative to produce $\beta$-galactosidase by $L$. reuteri, which is microbial growth-associated, and the production was not affected by increasing the culture medium volume.
\end{abstract}

Keywords: Lactobacillus reuteri, $\beta$-galactosidase, optimization.

Este estudo reporta a otimização dos parâmetros do meio de cultura em cultivo submerso para produzir $\beta$ galactosidase por Lactobacillus reuteri. Quatro parâmetros do meio de cultivo foram otimizados ( $\mathrm{pH}$, lactose, caseína e levedo de cerveja inativo) e o efeito de diferentes volumes do meio otimizado foi avaliado para a produção de $\beta$-galactosidase. Diferentes modelos cinéticos foram aplicados para prever a produção enzimática como função da biomassa e do substrato. Esta é a primeira vez que o efeito do aumento do volume do meio de cultura e a modelagem são estudados na produção de $\beta$-galactosidase por $L$. reuteri. Adicionalmente, diferentes parâmetros do bioprocesso foram calculados baseados nos dados experimentais para verificar a viabilidade da produção. A atividade enzimática no meio otimizado (12,75 $\mathrm{g} \mathrm{L}^{-1}$ de lactose; $1,88 \mathrm{~g} \mathrm{~L}^{-1}$ de caseína; $1,65 \mathrm{~g} \mathrm{~L}^{-1}$ de levedo de cerveja inativo e $\mathrm{pH}$ 5,61) foi aumentada em 4,74 vezes. Três volumes de meio de cultivo ( 200,800 e $3200 \mathrm{~mL}$ ) foram avaliados, e não foi observada diferença significativa entre os valores de produtividade máxima e total $\left(\mathrm{P}_{\mathrm{m}} \mathrm{e} \mathrm{P}_{\mathrm{p}}\right)$, bem como no fator de conversão de biomassa em produto $\left(\mathrm{Y}_{\mathrm{P} / \mathrm{X}}\right)$. O modelo Logístico resultou em bom ajuste aos dados experimentais em todos os volumes e o modelo de Luedeking-Piret modificado permitiu uma previsão satisfatória da atividade enzimática. O meio de cultura otimizado provou ser uma alternativa promissora para produzir $\beta$-galactosidase por $L$. reuteri, a qual é associada ao crescimento da bactéria lática, sendo que sua produção não foi afetada pelo aumento de volume do meio de cultura.

Palavras-chave: Lactobacillus reuteri, $\beta$-galactosidase, otimização. 


\section{INTRODUCTION}

$\beta$-galactosidase ( $\beta$-D-galactoside galactohydrolase, EC 3.2.1.23) has been used as a biocatalyst in the dairy industry to produce lactose-free dairy products, besides being applied in the production of galacto-oligosaccharides and also to enhance creaminess and sweetness in products since glucose and galactose are sweeter than lactose [1-4]. Due to the wide range of applications for this enzyme, it is projected to show an annual market growth rate of $3.7 \%$ from 2017, reaching more than US\$ 1,647 million in the market value of $\beta$-galactosidase by the end of 2025 [5].

$\beta$-galactosidase catalyses the $\beta(1 \rightarrow 4)$ hydrolysis of lactose, and it is found in plants, animals and microorganisms [6-10]. Among several microbial sources of this enzyme, lactic acid bacteria (LAB), such as Lactobacillus genus receive increasing attention since they are GRAS (generally recognized as safe), providing several beneficial functions to human health [11-15]. Moreover, the use of probiotic strains as bio factories for enzymes production has recently attracted great interest since extensive purification steps are not required for its application in the food and pharmaceutical industry [12].

In this scenario, Lactobacillus reuteri is recognized as a dominant GRAS strain of heterofermentative Lactobacillus with potential probiotic characteristics, such as the ability to produce antimicrobials $[16,17]$, to survive gastrointestinal $\mathrm{pH}[18,19]$ and, modulating immunity [20]. In addition, it has been studied for its ability to produce $\beta$-galactosidase [13, 16, 21-25]. It was confirmed in our previous study that $L$. reuteri achieved the highest levels of enzymatic activity, productivity, and yield factors, when compared against different lactic acid bacteria (six of the genus Lactobacillus sp., and two of the genus Pediococcus sp.), and a yeast (Kluyveromyces lactis) [25].

Carbon and nitrogen sources are essential to enhance the enzyme synthesis by LAB [7, 16, 21, $22,26,27]$. Several studies reported the use of yeast extract as a major nitrogen source to produce $\beta$-galactosidase by $L$. reuteri $[13,21,22]$, although its high cost may be a limiting factor regarding the scalability of the upstream processing $[7,25]$. It was verified that the commercial yeast extract presented more than 40 -fold higher cost when compared to the inactive beer yeast [25]. Thus, the use of a blend containing casein and inactive beer yeast may provide an economically viable alternative, since inactive beer yeast is considered a by-product obtained after the fermentation process of barley grains in the brewery industry.

In biotechnological processes, mathematical models such as Monod [28], Logistic [29] and Contois [30] are mainly used to relate kinetic growth and biomass production. However, when the purpose is to evaluate the production of biomolecules, a more robust type of modeling is required. The Luedeking-Piret model may be used for this purpose since it relates microbial growth and product formation [31].

To the best of our knowledge, no studies were reported before regarding either the optimization of bioprocess by using an alternative culture medium, or the effect of increasing the culture medium volume in terms of enzymatic production by $L$. reuteri. Furthermore, the use of mathematical modeling and the calculation of different kinetic parameters to evaluate the process feasibility by L. reuteri have not been previously studied.

The aims of this study are as follows: to maximize $\beta$-galactosidase production by Lactobacillus reuteri, with casein and inactive beer yeast as the main nitrogen sources, by optimization design; to evaluate the effect of increasing the culture medium volume on $\beta$-galactosidase activity; to identify the best mathematical model in relation to enzymatic activity and, based on these results, to determine whether $\beta$-galactosidase production is associated or not with $L$. reuteri growth. In addition, different bioprocess parameters were calculated to evaluate the process feasibility.

\section{MATERIAL AND METHODS}

\subsection{Microorganism maintenance and inoculum}

Lactobacillus reuteri B-14171 (NRRL - Agricultural Research Service Culture Collection, Peoria, United States) was maintained and reactivated in MRS broth (Man, Rogosa and Sharpe 
broth, Himedia ${ }^{\circledR}$, Mumbai, India) at $\mathrm{pH} 6.5 \pm 0.2$ and incubated at $37^{\circ} \mathrm{C}$ for 13 hours to prepare the inoculum. Subsequently, $0.1 \%$ of the inoculum (by volume, corresponding to a viable cell concentration of around $6 \log \mathrm{CFU} \mathrm{mL} \mathrm{m}^{-1}$ ) was transferred to an Erlenmeyer flask containing the culture medium for production of $\beta$-galactosidase [25].

\subsection{Experimental design and statistical analysis to increase $\beta$-galactosidase biosynthesis}

A previous study confirmed the use of casein and inactive beer yeast as alternative nitrogen sources to promote high enzymatic activity by $L$. reuteri, with a 1.83 -fold lower cost than the commercial MRS, with yeast extract [25]. Besides, it was verified that factors such as $\mathrm{pH}$ and the concentrations of lactose, casein, and inactive beer yeast were essential for $\beta$-galactosidase production [25]. Therefore, these variables (Table 1) were evaluated using a central composite rotatable design (CCRD) with four replicates at the central point and eight axial points (24 plus star configuration, with 24 runs). The fermentation parameters are described in the Fermentation process section.

Table 1. CCRD coded and decoded levels of independent variables: lactose $\left(X_{1}\right)$, casein $\left(X_{2}\right)$, inactive beer yeast $\left(X_{3}\right)$ and initial $\mathrm{pH}\left(X_{4}\right)$.

\begin{tabular}{ccccccc}
\hline \multirow{2}{*}{ Factor } & \multirow{2}{*}{ Name } & $\mathbf{- 2}$ & $\mathbf{- 1}$ & $\mathbf{0}$ & $\mathbf{+ 1}$ & $\mathbf{+ 2}$ \\
\hline $\mathbf{X}_{\mathbf{1}}$ & Lactose $\left(\mathrm{g} \mathrm{L}^{-1}\right)$ & 0.0 & 5.0 & 10.0 & 15.0 & 20.0 \\
$\mathbf{X}_{\mathbf{2}}$ & Casein $\left(\mathrm{g} \mathrm{L}^{-1}\right)$ & 0.0 & 0.75 & 1.5 & 2.25 & 3.0 \\
$\mathbf{X}_{\mathbf{3}}$ & Inactive beer yeast $\left(\mathrm{g} \mathrm{L}^{-1}\right)$ & 0.0 & 0.75 & 1.5 & 2.25 & 3.0 \\
$\mathbf{X}_{4}$ & Initial pH & 4.5 & 5.0 & 5.5 & 6.0 & 6.5 \\
\hline
\end{tabular}

The CCRD was developed and analyzed using Statistica ${ }^{\circledR} 7.0$ for Windows (Statsoft ${ }^{\circledR}$, United States). All the experiments were performed randomly, and the quantified response was $\beta$ galactosidase activity. The coefficient of determination $\left(\mathrm{R}^{2}\right)$ expressed the fit of the second order equation, and the statistical significance was determined by the F-test (ANOVA). The optimal conditions predicted by the model for $\beta$-galactosidase activity were experimentally confirmed.

\subsection{Fermentation process}

Submerged fermentation $(\mathrm{SmF})$ was performed in $250 \mathrm{~mL}$ Erlenmeyer flasks, under microaerophilic static conditions, with $100 \mathrm{~mL}$ of modified MRS (MMRS, lactose instead of glucose) with casein (Naarden ${ }^{\circledR}$, Naarden, Holland), inactive beer yeast (Brasil ${ }^{\circledR}$, São Paulo, Brazil, which consists of inactive yeast cells obtained after the fermentation process of barley grains in the brewery industry), hydrogenated potassium phosphate $\left(2.0 \mathrm{~g} \mathrm{~L}^{-1}\right.$, Merck ${ }^{\circledR}$, Kenilworth, United States), triammonium citrate $\left(2.0 \mathrm{~g} \mathrm{~L}^{-1}\right.$ Merck $^{\circledR}$, Kenilworth, United States), sodium acetate $(2.0 \mathrm{~g}$ $\mathrm{L}^{-1}$ Merck $^{\circledR}$, Kenilworth, United States), magnesium sulfate (0.2 $\mathrm{g} \mathrm{L}^{-1}$, Synth ${ }^{\circledR}$, Diadema, Brazil); manganese sulfate $\left(0.05 \mathrm{~g} \mathrm{~L}^{-1}\right.$ Synth $^{\circledR}$, Diadema, Brazil) and Tween 80 (1.0 g L ${ }^{-1}$ Synth $^{\circledR}$, Diadema, Brazil). Based on our previous study [25] regarding the selection of different microorganisms and the evaluation of seven different nitrogen sources on $\beta$-galactosidase production, it was verified that $L$. reuteri produces high levels of the enzyme, and the maximum enzymatic activity was achieved at $48 \mathrm{~h}$. Therefore after $48 \mathrm{~h}$ of fermentation, the samples were collected to determine the $\beta$-galactosidase activity. The experimental design was performed in duplicate, and the determination of $\mathrm{pH}$ throughout the fermentative processes was carried out by direct measurement of the culture broth using a pH meter (Luca-210 ${ }^{\circledR}$, Lucadema, São José do Rio Preto, Brazil). 


\subsection{Biomass separation and enzyme extraction}

Samples containing $8 \mathrm{~mL}$ of culture suspension were centrifuged (Centribio $80-2 \mathrm{~B}^{\circledR}$, Rhosse, Ribeirão Preto, Brazil) at $1,000 \mathrm{~g}$ for $10 \mathrm{~min}$. The supernatant was removed, and the biomass was washed with $8 \mathrm{~mL}$ of $0.1 \mathrm{M}$ phosphate buffer $(\mathrm{pH} 6.5 \pm 0.2)$ twice, followed by another centrifugation, and then the supernatant was discarded. The obtained pellet was suspended in the same buffer. Since the $\beta$-galactosidase produced by lactic acid bacteria is intracellular, the biomass was sonicated to release the enzyme [32], based on previous tests to evaluate the effect of different sonication cycles on the enzymatic activity (data not shown). The highest efficiency (in terms of relative activity) was observed when six cycles were used. Therefore, the washed biomass $(8 \mathrm{~mL})$ was sonicated with six cycles $(1$ cycle $=50 \mathrm{~s}$ sonication $+50 \mathrm{~s}$ in an ice bath) with $20 \mathrm{kHz}$ acoustic power using $60 \%$ power (Disrupter Eco-Sonics QR-500 ${ }^{\circledR}$, Ultronique, Indaiatuba, Brazil). The suspension was centrifuged at $1,000 \mathrm{~g}$ for $10 \mathrm{~min}$ and the $\beta$-galactosidase activity was determined in the supernatant.

\section{5 $\beta$-galactosidase activity assay}

The substrate $\left(2.5 \mathrm{mg} \mathrm{mL}^{-1}\right)$, o-nitrophenyl- $\beta$-D-galactoside (ONPG, Sigma Aldrich ${ }^{\circledR}$, San Luis, United States), was dissolved in $0.2 \mathrm{M}$ sodium phosphate buffer (pH 6.5). $0.25 \mathrm{~mL}$ of supernatant obtained after the sonication procedure was added to $1 \mathrm{~mL}$ of ONPG solution and the mixture was incubated at $37^{\circ} \mathrm{C}$ for $15 \mathrm{~min}$. The reaction was interrupted by the addition of $0.25 \mathrm{~mL}$ of $10 \%$ $\mathrm{Na}_{2} \mathrm{CO}_{3}$ solution $\left(\mathrm{m} \mathrm{V}^{-1}\right)$. The absorbance was measured at $420 \mathrm{~nm}$. One unit of activity (U) is defined as the amount of enzyme that catalyzes the release of $1 \mu \mathrm{mol}$ ONP per minute in the specific test conditions [33].

\subsection{Effect of different volumes of the culture medium on $\beta$-galactosidase activity}

Based on the data regarding the optimization of $\beta$-galactosidade production using CCRD, the effect of increasing the volume of the culture medium was tested using $500 \mathrm{~mL}, 2,000 \mathrm{~mL}$, and $5,000 \mathrm{~mL}$ Erlenmeyer flasks, with $200 \mathrm{~mL}, 800 \mathrm{~mL}$ and 3,200 mL MMRS, respectively, under microaerophilic static conditions at $37^{\circ} \mathrm{C}$ for $56 \mathrm{~h}$ (bacteriological culture incubator Q316M6 ${ }^{\circledR}$, Quimis, Diadema, Brazil). The samples were collected at time 0 and every four hours to determine the following: viable cell number; dry weight of biomass; lactose concentration; $\beta$-galactosidase activity; and $\mathrm{pH}$.

\subsection{Viable cell count}

Samples of $1 \mathrm{~mL}$ of fermented broth were diluted in $9 \mathrm{~mL}$ of $0.1 \%\left(\mathrm{~m} \mathrm{~V}^{-1}\right)$ peptone water $\left(\right.$ Himedia $^{\circledR}$, Mumbai, India). The viable cell number was determined using MRS agar (Himedia ${ }^{\circledR}$, Mumbai, India) plate count, with the pour plate technique used after incubation at $37^{\circ} \mathrm{C}$ for $48 \mathrm{~h}$ [34].

\subsection{Determination of microbial biomass}

Samples containing $10 \mathrm{~mL}$ of fermented broth were centrifuged (Centribio $80-2 \mathrm{~B}^{\circledR}$, Rhosse, Ribeirão Preto, Brazil) at 1,000 $\mathrm{g}$ for $10 \mathrm{~min}$. The supernatants were discarded, and the remaining pellets were washed with distilled water and centrifuged again. The washed biomass was dried (60 $\left.{ }^{\circ} \mathrm{C}\right)$ until constant mass [35].

\subsection{Determination of lactose concentration}

The lactose concentration was determined using the methodology described by Pirisino (1983) [36] with some modifications. The supernatants (culture broth after biomass separation) were 
properly diluted and filtered through $0.22 \mu$ m nylon membrane filters (Sigma Aldrich ${ }^{\circledR}$, San Luis, United States) prior to the analysis, and $10 \mu \mathrm{L}$ of each sample was injected into High Performance Liquid Chromatography equipment (2695 Alliance $^{\circledR}$, Waters, Milford, United States) coupled to a refractive index detector (RI, Waters ${ }^{\circledR}$, Milford, United States). The separation was carried out in an Aminex HPX-87H ${ }^{\circledR}$ column $(300 \times 7.8 \mathrm{~mm}, 9 \mu \mathrm{m}$ particle size, Bio-Rad, Hercules, United States) with a Micro-guard Cation $\mathrm{H}^{+}$pre-column ( 30 x $4.6 \mathrm{~mm}$, Bio-Rad, Hercules, United States) using $6.0 \mathrm{mM}$ of sulfuric acid (Fmaia ${ }^{\circledR}$, Belo Horizonte, Brazil) as a mobile aqueous phase in isocratic conditions. The flow used was $0.5 \mathrm{~mL} \mathrm{~min}^{-1}$ with a temperature set to $30{ }^{\circ} \mathrm{C}$ for both column and detector. The areas of the peaks were obtained and compared with a standard curve (linear range from 0 to $10 \% \mathrm{~m} \mathrm{~V}^{-1}$ lactose, $\mathrm{R}^{2}=0.9979$ ). The results were expressed as $\mathrm{g} \mathrm{L}^{-1}$.

\subsection{Bioprocess parameters evaluated in the production of $\beta$-galactosidase}

Based on the experimental data for all the volumes of culture media that were tested $(200 \mathrm{~mL}$, $800 \mathrm{~mL}$ and 3,200 mL MMRS), the product formation yield on substrate consumed ( $\left.\mathrm{Y}_{\mathrm{P} / \mathrm{S}}\right)$, product formation yield on biomass $\left(\mathrm{Y}_{\mathrm{P} / \mathrm{X}}\right)$, total productivity $\left(\mathrm{P}_{\mathrm{p}}\right)$, and maximum productivity $\left(\mathrm{P}_{\mathrm{m}}\right)$ were calculated using Equations $1-4$.

$$
\begin{gathered}
Y_{\bar{S}}\left(U g^{-1}\right)=\frac{\Delta P}{\Delta S}=\frac{P-P_{0}}{S_{0}-S} \\
Y_{\bar{X}}\left(U g^{-1}\right)=\frac{\Delta P}{\Delta X}=\frac{P-P_{0}}{X-X_{0}} \\
P_{P}\left(U L^{-1} h^{-1}\right)=\frac{P-P_{0}}{t_{f}} \\
P_{m}\left(U L^{-1} h^{-1}\right)=\frac{P_{\log }-P_{0 \log }}{t_{f l o g}}
\end{gathered}
$$

where, $\mathrm{X}$ and $\mathrm{X}_{0}=$ final and initial biomass concentrations $\left(\mathrm{g} \mathrm{L}^{-1}\right) ; \mathrm{S}$ and $\mathrm{S}_{0}=$ final and initial substrate concentrations $\left(\mathrm{g} \mathrm{L}^{-1}\right) ; \mathrm{P}$ and $\mathrm{P}_{0}=$ final and initial product concentrations $\left(\mathrm{U} \mathrm{mL}^{-1}\right) ; \mathrm{t}_{\mathrm{f}}$ is the fermentation time; $\mathrm{P}_{\log }$ and $\mathrm{P}_{0 \log }=$ final and initial product concentrations in the log phase; and $\mathrm{t}_{\mathrm{flog}}$ is the log phase fermentation time.

\subsection{Statistical analysis}

Three separate experiments replicates were performed, and the results were expressed as mean $\pm \mathrm{sd}$ (standard deviation). The mean comparison between the evaluated bioprocess parameters was performed using analysis of variance (ANOVA). The homogeneity of the groups was identified and the differences between the means were assessed using the post-Tukey test with a $95 \%$ confidence level $(\mathrm{p} \leq 0.05)$. The analysis was performed using Statistica ${ }^{\circledR}$ software 7.0 for Windows (Statsoft ${ }^{\circledR}$, United States). The kinetic graphs were plotted using OriginPro ${ }^{\circledR} 8.1$ for Windows software (OriginLab ${ }^{\circledR}$, United States).

\subsection{Mathematical modeling}

The experimental data regarding biomass, substrate concentration and $\beta$-galactosidase activity for the three volumes of culture media were analyzed using the Logistic [29] and Contois [30] models. The Monod model [28] was tested for the experimental data; however, the adjustment was not satisfactory (data not shown). In addition, a modified Luedeking-Piret model [31], was used to 
compare the experimental data regarding the enzymatic activity for the different volumes of culture media that were tested. A more detailed description of these methods can be found in the Appendix.

The following kinetic parameters were evaluated using the Logistic and Contois models: $X_{\max }$ (maximum biomass concentration, $\mathrm{g} \mathrm{L}^{-1}$ ); $\mu_{\max }$ (maximum specific growth rate, $\mathrm{h}^{-1}$ ); $\mathrm{B}$ (biomass coefficient); $\mathrm{K}_{\mathrm{s}}$ (substrate saturation constant, $\mathrm{g} \mathrm{L}^{-1}$ ); $\mathrm{Y}_{\mathrm{X} / \mathrm{S}}$ (biomass yield on substrate consumed, $\mathrm{g}$ $\left.\mathrm{g}^{-1}\right) ; \alpha$ and $\beta$ (growth-dependent and non-dependent coefficients of microbial growth); and $\mathrm{P}$ ( $\beta$ galactosidase activity, $\mathrm{U} \mathrm{mL}^{-1}$ ).

The kinetic parameters were estimated assuming an initial set of values, which are generally obtained from the experimental data. The sum of squares of the error between the predicted and the experimental values $\left(\mathrm{R}^{2}\right)$ was determined. The best fit was identified, suggesting the most appropriate kinetic model and kinetic parameters associated with the model. The estimation of the parameters was carried out by a routine in Python using SciPy (version 1.0.0) and NumPy (version 1.14.1) libraries. The routine was based on the least square method, which aims to minimize an objective function defined as the square sum of the differences between the values estimated by the model and the experimental values.

\section{RESULTS AND DISCUSSION}

\subsection{Optimization of $\beta$-galactosidase production}

The independent variables (lactose, casein, inactive beer yeast, and $\mathrm{pH}$ ), as well as the responses ( $\beta$-galactosidase activity) that were predicted and obtained, are presented in Table 2 . The $\beta$ galactosidase activity values ranged from 0.000 to $7.004 \mathrm{U} \mathrm{mL}^{-1}$. There was no $\beta$-galactosidase activity at $\mathrm{pH} 4.5$ (level -2 , run 23), while the highest values were observed when all the independent variables were used at the values of the central point (level 0 , runs 25 - 28).

Table 2. Central composite rotatable design (CCRD) for production of $\beta$-galactosidase by Lactobacillus reuteri $B-14171$ in $\mathrm{SmF}$ at $37^{\circ} \mathrm{C}$ for $48 \mathrm{~h}$.

\begin{tabular}{|c|c|c|c|c|c|c|}
\hline \multirow{3}{*}{ Runs } & \multicolumn{4}{|c|}{ Codified independent variables } & \multirow[t]{3}{*}{$\begin{array}{c}\text { Observed } \\
\text { response } \\
\left(\mathbf{U} \mathbf{m L}^{-1}\right)^{\mathrm{a}}\end{array}$} & \multirow[t]{3}{*}{$\begin{array}{c}\text { Predicted } \\
\text { response } \\
\left(\mathrm{U} \mathrm{mL}^{-1}\right)\end{array}$} \\
\hline & $\begin{array}{c}\text { Lactose } \\
\left(\mathrm{g} \mathrm{L} \mathrm{L}^{-1)}\right.\end{array}$ & $\begin{array}{l}\text { Casein } \\
\left(\mathrm{g} \mathrm{L}^{-1}\right)\end{array}$ & $\begin{array}{c}\text { Inactive } \\
\text { beer yeast } \\
\left(\mathrm{g} \mathrm{L}^{-1}\right)\end{array}$ & pH & & \\
\hline & $\overline{X_{1}}$ & $\mathbf{X}_{2}$ & $\mathbf{X}_{3}$ & $\overline{X_{4}}$ & & \\
\hline 1 & -1 & -1 & -1 & -1 & $0.386 \pm 0.02$ & 0.503 \\
\hline 2 & -1 & -1 & -1 & +1 & $0.248 \pm 0.03$ & 0.115 \\
\hline 3 & -1 & -1 & +1 & -1 & $0.665 \pm 0.12$ & 0.560 \\
\hline 4 & -1 & -1 & +1 & +1 & $0.738 \pm 0.32$ & 0.581 \\
\hline 5 & -1 & +1 & -1 & -1 & $0.951 \pm 0.04$ & 1.153 \\
\hline 6 & -1 & +1 & -1 & +1 & $1.935 \pm 0.93$ & 1.813 \\
\hline 7 & -1 & +1 & +1 & -1 & $1.092 \pm 0.12$ & 1.269 \\
\hline 8 & -1 & +1 & +1 & +1 & $2.226 \pm 0.10$ & 2.298 \\
\hline 9 & +1 & -1 & -1 & -1 & $1.386 \pm 0.07$ & 1.176 \\
\hline 10 & +1 & -1 & -1 & +1 & $1.772 \pm 0.22$ & 1.745 \\
\hline 11 & +1 & -1 & +1 & -1 & $1.590 \pm 0.15$ & 1.861 \\
\hline 12 & +1 & -1 & +1 & +1 & $3.139 \pm 0.32$ & 2.798 \\
\hline 13 & +1 & +1 & -1 & -1 & $2.310 \pm 0.40$ & 2.616 \\
\hline 14 & +1 & +1 & -1 & +1 & $4.306 \pm 0.72$ & 4.233 \\
\hline 15 & +1 & +1 & +1 & -1 & $3.327 \pm 0.53$ & 3.321 \\
\hline 16 & +1 & +1 & +1 & +1 & $5.274 \pm 0.39$ & 5.306 \\
\hline
\end{tabular}


Table 2. (continued)

\begin{tabular}{|c|c|c|c|c|c|c|}
\hline \multirow{3}{*}{ Runs } & \multicolumn{4}{|c|}{ Codified independent variables } & \multirow{3}{*}{$\begin{array}{c}\text { Observed } \\
\text { response } \\
\left(\mathbf{U} \mathbf{m L}^{-1}\right)^{\mathrm{a}}\end{array}$} & \multirow{3}{*}{$\begin{array}{c}\text { Predicted } \\
\text { response } \\
\left(\mathrm{U} \mathrm{mL}^{-1}\right)\end{array}$} \\
\hline & $\begin{array}{c}\text { Lactose } \\
\left(\mathrm{g} \mathrm{L} \mathrm{L}^{-1)}\right.\end{array}$ & $\begin{array}{l}\text { Casein } \\
\left(\mathrm{g} \mathrm{L}^{-1}\right)\end{array}$ & $\begin{array}{c}\text { Inactive } \\
\text { beer yeast } \\
\left(\mathrm{g} \mathrm{L}^{-1}\right)\end{array}$ & pH & & \\
\hline & $\mathbf{X}_{1}$ & $\mathbf{X}_{2}$ & $\mathbf{X}_{3}$ & $\mathbf{X}_{4}$ & & \\
\hline 17 & -2 & 0 & 0 & 0 & $0.622 \pm 0.12$ & 0.560 \\
\hline 18 & +2 & 0 & 0 & 0 & $4.234 \pm 0.71$ & 4.264 \\
\hline 19 & 0 & -2 & 0 & 0 & $0.777 \pm 0.02$ & 1.055 \\
\hline 20 & 0 & +2 & 0 & 0 & $4.500 \pm 0.95$ & 4.212 \\
\hline 21 & 0 & 0 & -2 & 0 & $1.821 \pm 0.21$ & 1.796 \\
\hline 22 & 0 & 0 & +2 & 0 & $2.952 \pm 0.54$ & 2.966 \\
\hline 23 & 0 & 0 & 0 & -2 & $0.000 \pm 0.00$ & -0.390 \\
\hline 24 & 0 & 0 & 0 & +2 & $0.827 \pm 0.02$ & 1.208 \\
\hline 25 & 0 & 0 & 0 & 0 & $6.980 \pm 0.87$ & 6.442 \\
\hline 26 & 0 & 0 & 0 & 0 & $7.004 \pm 0.32$ & 6.442 \\
\hline 27 & 0 & 0 & 0 & 0 & $6.157 \pm 0.26$ & 6.442 \\
\hline 28 & 0 & 0 & 0 & 0 & $5.625 \pm 0.53$ & 6.442 \\
\hline
\end{tabular}

* Symbols $\mathrm{X}_{1}, \mathrm{X}_{2}, \mathrm{X}_{3}$ and $\mathrm{X}_{4}$ are the same as in Table 1 .

a The results are expressed as mean \pm sd.

From the analysis of the effects (data not shown), the $\beta$-galactosidase activity was observed to be mostly influenced by the initial concentrations of lactose, casein and inactive beer yeast, and the initial $\mathrm{pH}$, whose linear terms had highly significant and positive effects $(\mathrm{p}<0.0001$, lactose; $\mathrm{p}<$ 0.0001 , casein; $\mathrm{p}<0.05$, inactive beer yeast and, $\mathrm{p}<0.001, \mathrm{pH}$ ). In other words, the increase in the concentrations of these variables causes an increase in $\beta$-galactosidase activity.

The quadratic terms of all the variables had a significant and negative effect on the following responses: initial concentrations of lactose, casein and inactive beer yeast, and $\mathrm{pH}(\mathrm{p}<0.0001)$. The interactions between the initial lactose concentration and initial $\mathrm{pH}\left(\mathrm{X}_{1} \mathrm{X}_{4}\right)$, and between the initial casein concentration and initial $\mathrm{pH}\left(\mathrm{X}_{2} \mathrm{X}_{4}\right)$, had a significant effect on the response $(\mathrm{p}=0.041$ and $p=0.027$, respectively). These results indicate the influence of carbon and nitrogen sources, and the initial $\mathrm{pH}$ on $\beta$-galactosidase activity. Many authors have reported the importance of culture conditions, such as initial $\mathrm{pH}$ and the concentrations of lactose and nitrogen sources, on enzymatic production $[7,13,25,27,37,38]$. Although the production of microbial $\beta$-galactosidase is influenced by the initial $\mathrm{pH}$ of the culture medium, this physicochemical parameter varies according to the microorganism producer. Studies aiming to produce $\beta$-galactosidase from lactic acid bacteria have reported $\mathrm{pH}$ ranges from 6.0 to 7.5 of the culture media $[16,39,40]$. In our study the $\mathrm{pH}$ ranged from 4.5 to 6.5 , with the highest values for enzymatic activity observed between 5.5 and 6.5.

The carbon and nitrogen sources are considered the most important limiting factor for microbial growth and metabolic regulation. Since $\beta$-galactosidase is an inducible enzyme, the culture medium should provide lactose as a carbon source, as well as amino acids for its production [41, 42]. Analysis of variance (ANOVA) was performed considering all terms due to the influence of the variables on $\beta$-galactosidase activity, and because the exclusion of any of the terms could worsen the adequacy of the model in relation to the predicted response. The results are reported in Table 3.

The $\mathrm{R}^{2}$ value $(0.981)$ agreed with the adjusted $\mathrm{R}^{2}(0.961)$, which demonstrated the adequacy of the model in terms of the predicted response. The model is highly significant at $95 \%$ level of significance $(\mathrm{p} \leq 0.05)$ since the maximum variation that the model could explain was $98.99 \%$. The F-value calculated for the model was significant $\left(\mathrm{F}_{\mathrm{cal}}>\mathrm{F}_{\mathrm{tab}}\right)$ and the lack-of-fit test $\left(\mathrm{F}_{\text {cal }}=0.210\right)$ showed that it was not significant in relation to the pure error $\left(\mathrm{F}_{\mathrm{tab}}=8.786\right)$, confirming that the experimental data satisfactorily fitted the model. As a result, the following equation was obtained using the multivariate polynomial regression technique (Eq. 5). 


$$
\begin{aligned}
Y= & 6.442+0.920 \mathrm{X}_{1}-1.005 \mathrm{X}_{1}^{2}+0.798 \mathrm{X}_{2}-0.952 \mathrm{X}_{2}^{2}+0.292 \mathrm{X}_{3}-1.015 \mathrm{X}_{3}^{2} \\
& +0.399 \mathrm{X}_{4}-1.508 \mathrm{X}_{4}^{2}+0.239 \mathrm{X}_{1} \mathrm{X}_{4}+0.262 \mathrm{X}_{2} \mathrm{X}_{4}
\end{aligned}
$$

where $\mathrm{Y}=\beta$-galactosidase activity $\left(\mathrm{U} \mathrm{mL}^{-1}\right), \mathrm{X}_{1}=$ initial lactose concentration $\left(\mathrm{g} \mathrm{L}^{-1}\right), \mathrm{X}_{2}=$ initial casein concentration $\left(\mathrm{g} \mathrm{L}^{-1}\right), \mathrm{X}_{3}=$ initial inactive beer yeast concentration $\left(\mathrm{g} \mathrm{L}^{-1}\right)$ and $\mathrm{X}_{4}=$ initial $\mathrm{pH}$.

Table 3. Analysis of variance (ANOVA) for the experimental results of the quadratic model obtained by $C C R D$ for $\beta$-galactosidase activity produced by Lactobacillus reuteri B-14171 in SmF at $37^{\circ} \mathrm{C}$ for $48 \mathrm{~h}$.

\begin{tabular}{cccccc}
\hline Source $^{*}$ & SS & DF & MS & F & p \\
\hline Model & 119.598 & 14 & 8.543 & 48.263 & $<0.00001$ \\
$\mathbf{X}_{\mathbf{1}}$ & 20.327 & 1 & 20.327 & 114.842 & $<0.00001$ \\
$\mathbf{X}_{\mathbf{2}}$ & 14.954 & 1 & 14.954 & 84.486 & $<0.00001$ \\
$\mathbf{X}_{\mathbf{3}}$ & 2.052 & 1 & 2.052 & 11.592 & 0.005 \\
$\mathbf{X}_{\mathbf{4}}$ & 3.829 & 1 & 3.829 & 21.634 & 0.0004 \\
$\mathbf{X}_{\mathbf{1}}{ }^{2}$ & 24.224 & 1 & 24.224 & 136.855 & $<0.00001$ \\
$\mathbf{X}_{\mathbf{2}}{ }^{2}$ & 21.753 & 1 & 21.753 & 122.894 & $<0.00001$ \\
$\mathbf{X}_{\mathbf{3}}{ }^{2}$ & 24.730 & 1 & 24.730 & 139.712 & $<0.00001$ \\
$\mathbf{X}_{\mathbf{4}}{ }^{2}$ & 54.591 & 1 & 54.591 & 308.415 & $<0.00001$ \\
$\mathbf{X}_{\mathbf{1}} \mathbf{X}_{\mathbf{2}}$ & 0.625 & 1 & 0.625 & 3.533 & 0.083 \\
$\mathbf{X}_{\mathbf{1}} \mathbf{X}_{\mathbf{3}}$ & 0.346 & 1 & 0.346 & 1.955 & 0.185 \\
$\mathbf{X}_{\mathbf{1}} \mathbf{X}_{\mathbf{4}}$ & 0.915 & 1 & 0.915 & 5.169 & 0.041 \\
$\mathbf{X}_{\mathbf{2}} \mathbf{X}_{\mathbf{3}}$ & 0.000 & 1 & 0.000 & 0.002 & 0.965 \\
$\mathbf{X}_{\mathbf{2}} \mathbf{X}_{\mathbf{4}}$ & 1.098 & 1 & 1.098 & 6.204 & 0.027 \\
$\mathbf{X}_{\mathbf{3}} \mathbf{X}_{\mathbf{4}}$ & 0.136 & 1 & 0.136 & 0.768 & 0.397 \\
Residue & 2.301 & 13 & 0.177 & & \\
Lack-of-fit & 0.947 & 10 & 0.095 & 0.210 & 0.974 \\
Pure error & 1.3537 & 3 & 0.451 & & \\
Total & 121.899 & 27 & & & \\
\hline
\end{tabular}

* Symbols $\mathrm{X}_{1}, \mathrm{X}_{2}, \mathrm{X}_{3}$ and $\mathrm{X}_{4}$ are the same as in Table 1 .

SS: sum of squares; DF: degrees of freedom; MS: mean of squares.

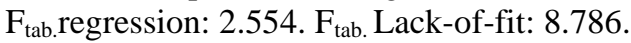

$\mathrm{R}^{2}: 0.981 ; \mathrm{R}^{2}$ adjust: 0.961 ; maximum variation explained: $98.99 \%$.

Equation 5 was used to construct 3D response surface graphs and their respective contour curves. The response surface was obtained through the interaction between the initial lactose concentration and $\mathrm{pH}$ (Figure 1a) and between initial casein concentration and $\mathrm{pH}$ (Figure 1b), which presented significant effects on the $\beta$-galactosidase activity, keeping other variables in their central point. The peaks in the response surface suggest that the optimal activity points were within the limits of the experimental design. The interactions between the variables were highly significant, with an elliptical order to the contour points, indicating the high level of influence on the enzymatic activity.

For an initial lactose concentration greater than 5.0 up to $15.0 \mathrm{~g} \mathrm{~L}^{-1}$, with the initial $\mathrm{pH}$ between 5.0 and 5.5, the optimal $\beta$-galactosidase activity was greater than $6.0 \mathrm{U} \mathrm{mL}^{-1}$ (Fig. 1a). The same enzymatic activity was observed (greater than $6.0 \mathrm{U} \mathrm{mL}^{-1}$ ) for the initial casein concentration greater than 0.75 up to $2.25 \mathrm{~g} \mathrm{~L}^{-1}$ with the same range of $\mathrm{pH}$ (Fig. 1b). The optimal values of the independent variables to maximize enzymatic activity were as follows: $12.75 \mathrm{~g} \mathrm{~L}^{-1}$ lactose; $1.88 \mathrm{~g}$ $\mathrm{L}^{-1}$ casein and $1.65 \mathrm{~g} \mathrm{~L}^{-1}$ inactive beer yeast concentrations; and $\mathrm{pH} 5.61$ in MMRS. Tests were carried out in these optimal conditions to validate the optimization model and the $\beta$-galactosidase activity observed was $7.28 \pm 0.22 \mathrm{U} \mathrm{mL}^{-1}$. There was no statistically significant difference from the result predicted by the optimization model $\left(6.97 \mathrm{U} \mathrm{mL}^{-1}-\right.$ absolute error $\left.=4.26 \%\right)$ when applying the Tukey test at $95 \%$ significance level. Since both values were similar (low absolute error - below $5 \%$ ) the optimization model could be considered as predictive within the studied range. 
(a)

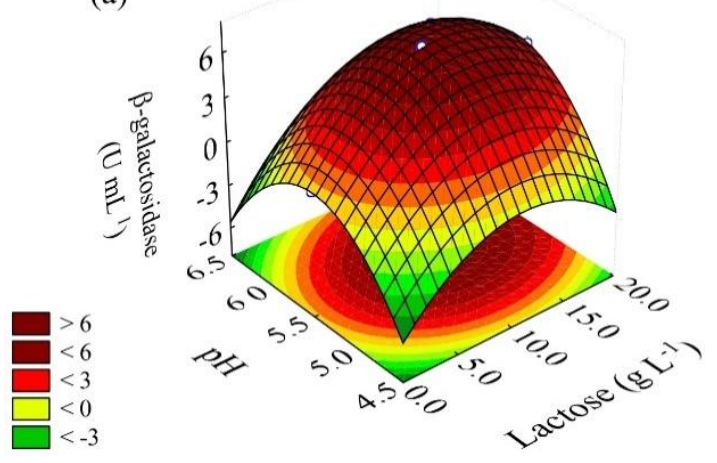

(b)

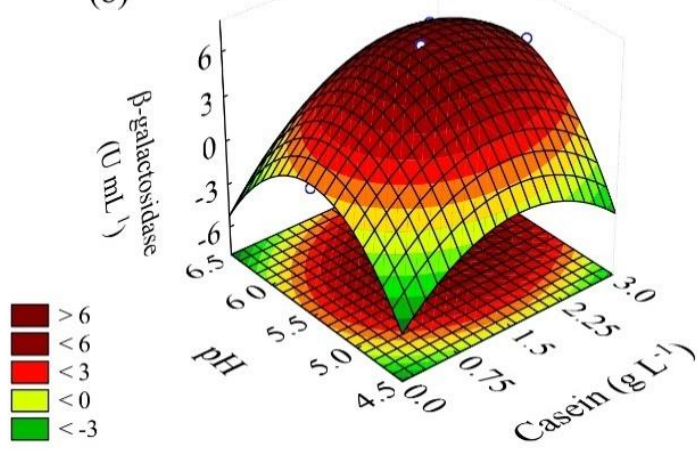

Figure 1. Response surface graphs for $\beta$-galactosidase activity produced by Lactobacillus reuteri B-14171 in $\mathrm{SmF}$ at $37^{\circ} \mathrm{C}$ for $48 \mathrm{~h}$. showing: (a) interaction between initial lactose concentration $\left(X_{I}\right)$ and initial $\mathrm{pH}$ $\left(X_{4}\right)$, keeping the initial casein and inactive beer yeast in the central point; and $(b)$ interaction between initial casein concentration $\left(\mathrm{X}_{2}\right)$ and initial $\mathrm{pH}\left(\mathrm{X}_{4}\right)$, keeping the initial lactose and inactive beer yeast concentrations in the central point.

The enzymatic activity observed in our previous study was $1.27 \mathrm{U} \mathrm{mL}^{-1}$ without optimized culture media conditions [25]. With the optimized medium, the initial $\beta$-galactosidase activity by L. reuteri B-14171 increased 4.74-fold, confirming the efficiency of the optimization. Carevic et al. (2015) [11] optimized the $\beta$-galactosidase activity from Lactobacillus acidophilus using a modified MRS medium, with lactose $\left(25 \mathrm{~g} \mathrm{~L}^{-1}\right)$ as carbon source and peptone $\left(10 \mathrm{~g} \mathrm{~L}^{-1}\right)$, meat extract $\left(10 \mathrm{~g} \mathrm{~L}^{-1}\right)$ and yeast extract $\left(5 \mathrm{~g} \mathrm{~L}^{-1}\right)$ as nitrogen sources. The authors reported $2.10 \mathrm{U} \mathrm{mL}^{-1}$ of enzymatic activity, which is three-fold lower than the activity reported in this study. It is known that different carbon and nitrogen concentrations affect enzymatic activity. Based on our results, higher $\beta$-galactosidase activity was achieved when lower concentrations of carbon and nitrogen sources were used, proving the high potential of these low-cost sources for $\beta$-galactosidase production by $L$. reuteri.

\subsection{Effect of different volumes of the culture medium on $\beta$-galactosidase activity}

The fermentation profiles are presented in Figure 2 for $\beta$-galactosidase production by Lactobacillus reuteri B-14171 using different volumes of optimized MMRS medium. In all the tested volumes of optimized MMRS broth, the highest concentration of viable cells occurred at 48 $\mathrm{h}\left(11.17 ; 11.10\right.$ and $11.04 \log \mathrm{CFU} \mathrm{mL} \mathrm{m}^{-1}$ in $200 ; 800$ and 3,200 mL, respectively), and correlate with the highest enzymatic activity $\left(7.75 ; 7.10\right.$ and $6.46 \mathrm{U} \mathrm{mL}^{-1}$, respectively) that was observed at the end of the log growth phase (Fig. 2). Hidalgo-Morales et al. (2005) [16] verified the same behavior when testing $\beta$-galactosidase production using $L$. reuteri in a commercial MRS medium, with lactose as a carbon source and skimmed milk medium (12\%).

It is possible to note that maximum enzymatic activity was slightly affected by increasing the culture medium volume, where a reduction of around $17 \%$ of $\beta$-galactosidase activity occurred. Moreover, when culture medium volume increased from 200 to $3,200 \mathrm{~mL}$, another reduction (of around 10\%) in the biomass levels (data not shown) was observed. This fact may explain the reduction in enzymatic activity, especially when the production of the enzyme is associated with microbial growth. This growth-association will be discussed in the next section, where mathematical models were applied to elucidate the assumption. Despite the reduction of enzymatic activity, these values suggest that lactic acid bacteria presented an excellent ability to produce $\beta$ galactosidase.

The produced $\beta$-galactosidase is transported in the cells by the lactose-permease system of the enzyme [43-46]. All the genes involved in the synthesis are located next to each other on the chromosome and, together, they form a lac operon. In lactic acid bacteria, the structural genes might be lacL, lacM, and LacZ, and they are responsible for the lactose hydrolysis [43, 45, 47]. The regulation of such genes depends on the availability of the substrate [7, 44, 48]. 
Lactose constitutes the carbon source needed to produce $\beta$-galactosidase since it induces enzymatic production [49]. The lactose concentration found at the beginning of the fermentative processes (approximately $11.60 \mathrm{~g} \mathrm{~L}^{-1}$ ) was lower than that used to prepare the culture medium (12.75 $\left.\mathrm{g} \mathrm{L}^{-1}\right)$. This reduction might have been caused by the autoclaving, which led to the Maillard reaction, since a slight color change was observed after this process [50,51]. The same behavior was verified in a previous study by Gomes et al. (2018) [25].

Substrate consumption (lactose) was observed from $8 \mathrm{~h}$ onwards, although there was an increase in the viable cell count from $4 \mathrm{~h}$ in all runs (Fig. 2). In the first growth stage, the lactic acid bacteria may have consumed the carbon source present in the casein and inactive beer yeast for its growth and metabolism. This result suggests that the enzyme biosynthesis was not affected, since the consumption of lactose as the main carbon source was observed after $8 \mathrm{~h}$ of fermentation, reaching its highest level of enzymatic activity at the end of the log growth phase. Lactose as the main carbon source in enzymatic production and its importance was reported previously [21, 23, 41, 44, 52, 53]. Carevic et al. (2016) [23] evaluated the effect of different carbon sources on $\beta$-galactosidase activity and observed that enzymatic activity was highly pronounced by the presence of $2.0 \%$ lactose in the culture medium.

As observed in the optimization of $\beta$-galactosidase production (previous section), the nitrogen sources also affect the enzymatic activity. According to Von Wright and Axelsson (2011) [54] and Vasiljevic and Jelen (2001) [37], lactic acid bacteria need a complex media rich in amino acids for their growth and biomolecule production. Casein and inactive beer yeast have a similar amino acids composition $[55,56]$ as well as a high concentration of glutamic and aspartic acids and cysteine, which are known to induce the production of $\beta$-galactosidase [7].

After $8 \mathrm{~h}$ of fermentation, the beginning of the log phase could be observed up to $48 \mathrm{~h}$; while enzymatic activity started to increase after $20 \mathrm{~h}$, when there was an increase in the biomass of around $3 \log \mathrm{CFU} \mathrm{mL} \mathrm{m}^{-1}$ in all the evaluated processes. This result may indicate the balance between the free enzyme (evaluated $\beta$-galactosidase activity) and the enzyme bond to the substrate. When the substrate concentration decreases, most probably the amount of free enzyme increases. Also, the lactic acid bacteria might have produced a small amount of enzyme, aiming to consume substrate for its growth and cellular maintenance in the first $20 \mathrm{~h}$.

The $\mathrm{pH}$ values slowly reduced in the first hours of fermentation and reduced at faster rate between 16 and $28 \mathrm{~h}$, stabilizing around 4.0 and 4.1 (Fig. 2). The reduction in $\mathrm{pH}$ occurred at the same time as the beginning of the increase in enzymatic activity, mainly related to the production of lactic acid by L. reuteri B-14171 [16]. The reduction in enzymatic activity after $48 \mathrm{~h}$ matched with the reduction of the viable cell count, which corroborates with the assumption that $\beta$ galactosidase production is associated with microbial cell growth. The same behavior was verified by Hsu et al. (2005) [41] for $\beta$-galactosidase produced by Bifidobacterium longum. 

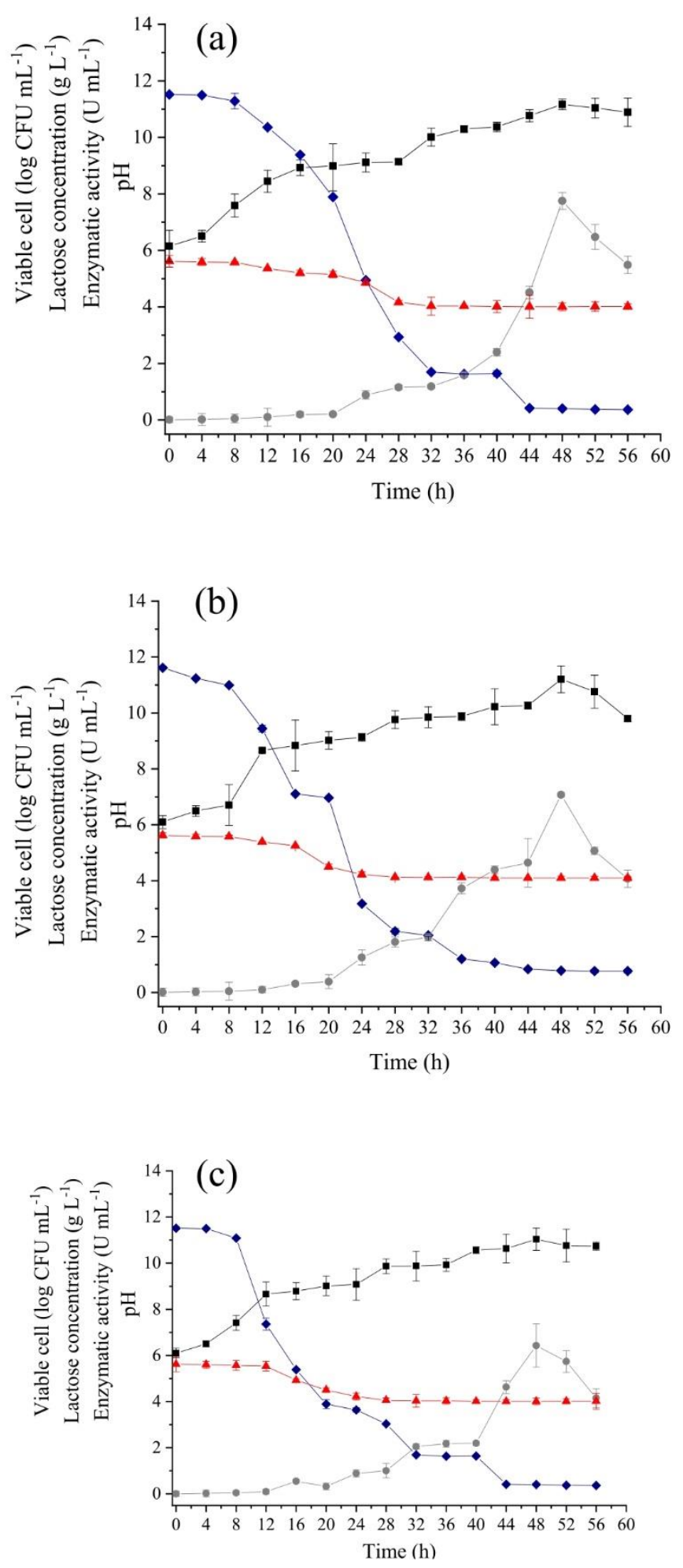

- Viable cell count - Lactose concentration

$\rightarrow \beta$-galactosidase activity $\quad \Delta \mathrm{pH}$

Figure 2. Profile of the parameters evaluated during fermentation for $\beta$-galactosidase production by Lactobacillus reuteri B-14171 in $200 \mathrm{~mL}(\mathrm{a})$; $800 \mathrm{~mL}$ (b) and 3,200 mL (c) of optimized MMRS medium. 
As a main achievement, it was observed that the values for maximum enzymatic activity were higher than previously reported studies using commercial MRS medium with $20.0 \mathrm{~g} \mathrm{~L}^{-1}$ lactose. Values of around 0.33 and $5.08 \mathrm{U} \mathrm{mL}^{-1}$ were reported by Nguyen et al. (2006) [21] and $4.0 \mathrm{U} \mathrm{mL}^{-}$ ${ }^{1}$ by Hidalgo-Morales et al. (2005) [16]. In this work were observed activities of 7.75; 7.10 and 6.46 $\mathrm{U} \mathrm{m} \mathrm{L}{ }^{-1}$, for the three tested volumes, respectively. Therefore, the use of casein and inactive beer yeast achieves high levels of $\beta$-galactosidase activity also when the culture media volumes were increased.

\subsection{Kinetic models for the prediction of biomass production and $\beta$-galactosidase activity}

In this study, the biomass production and the substrate consumption were evaluated using the Logistic (Eq. A.1 - Appendix) and Contois (Eq. A.2 - Appendix) models. Based on the results from Logistic and Contois models, the modified Luedeking-Piret model (Eq. A.3-Appendix) was applied to predict the enzyme production by L. reuteri, and they are now called Contois-based modified Luedeking-Piret (CbMLP) and Logistic-based modified Luedeking-Piret (LbMLP). Figure 3 shows the comparison between the experimental data with the prediction of the different mathematical models for the three volumes of optimized culture medium that were tested.

The first evaluated statistical parameter was the $\mathrm{R}^{2}$ provided by each tested model (solid lines in Fig. 3). It was verified that both Logistic and Contois models fitted the experimental data regarding the substrate consumption, with high $\mathrm{R}^{2}$ values $(0.991,0.982$ and 0.953 for 200,800 and 3,200 mL, respectively for the Logistic model; and 0.990, 0.983 and 0.971 for 200, 800 and 3,200 $\mathrm{mL}$, respectively for the Contois model, Table 4$)$. For the fitted $\beta$-galactosidase activity (product), the LbMLP model presented $\mathrm{R}^{2}$ values slightly higher $(0.975,0.977$ and 0.968 for 200,800 and $3,200 \mathrm{~mL}$, respectively) than the CbMLP model (0.974, 0.971 and 0.961 for 200,800 and 3,200 $\mathrm{mL}$, respectively). Regarding the fitted biomass data, although the $\mathrm{R}^{2}$ values were higher than 0.880 (Table 4), it is possible to note that both Logistic and Contois models did not fit biomass data perfectly, mainly during the log growth phase (black color, Fig. 3). Therefore, to determine which model better predicted the experimental data, it was necessary to discuss each parameter provided by each model individually.
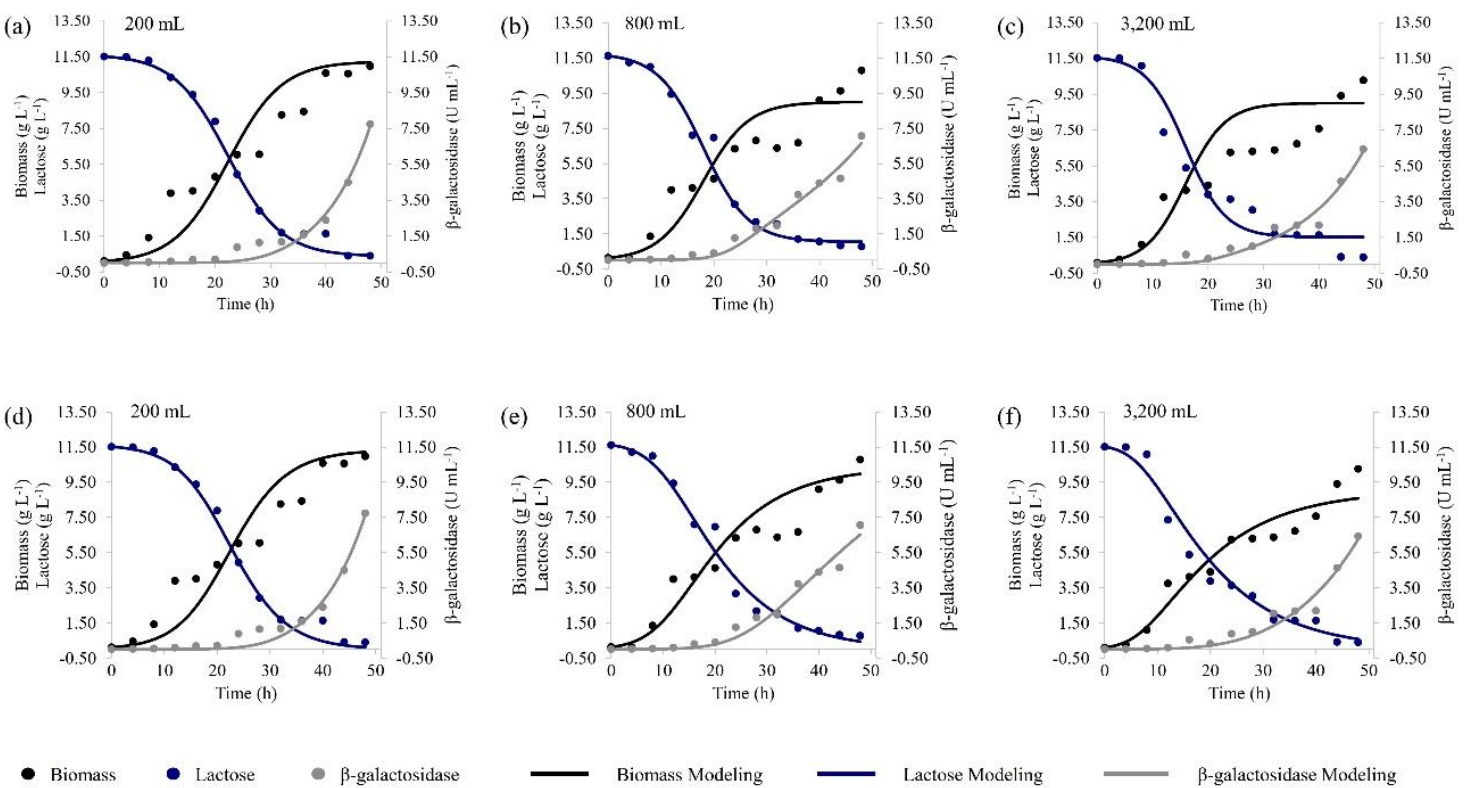

Figure 3. Experimental data (•) and model predictions (-) of biomass (black color); lactose consumption (blue color) and $\beta$-galactosidase activity (grey color) for the Logistic model in: (a) $200 \mathrm{~mL}$, (b) $800 \mathrm{~mL}$, and (c) 3,200 mL; and for the Contois model in: (d) $200 \mathrm{~mL}$, (e) $800 \mathrm{~mL}$, and (f) 3,200 $\mathrm{mL}$ of MMRS medium. 
The parameters adjusted by the models (Logistic and Contois) for biomass production $\left(\mu_{\max }\right.$, $\mathrm{X}_{\max }$ ), biomass yield on substrate consumed $\left(\mathrm{Y}_{\mathrm{X} / \mathrm{S}}\right)$, and the modified Luedeking-Piret models (LbMLP and CbMLP) for $\beta$-galactosidase activity ( $\alpha$ and $\beta$ coefficients) are shown in Table 4 . The parameters were adjusted using the symfit optimization package [57], available in Python language. The difference between the values predicted by the model and the experimental data was used as an objective function, with the algorithm aiming to minimize this value.

The maximum growth rate $\left(\mu_{\max }\right)$ did not vary using the Logistic model, whereas there was a high level of variation concerning the Contois model. The latter has an additional parameter referring to the substrate (S) that controls how the curvature changes, which is the reason why the curvatures and their values for $\mu_{\max }$ were different for the different evaluated volumes. In the Logistic model, the lack of this parameter made the curve behave similarly for all the evaluated volumes (Fig. 3). For both models, the $\mu_{\max }$ was highest $\left(0.281\right.$ and $0.407 \mathrm{~h}^{-1}$ for the Logistic and Contois models, respectively) in 3,200 $\mathrm{mL}$ of optimized MMRS medium, indicating that the maximum specific growth rate is achieved when the volume of the culture medium increased.

On the other hand, biomass production and enzymatic activity were affected by increasing the culture medium volume. The maximum biomass concentration $\left(\mathrm{X}_{\max }\right)$ calculated by the Logistic model was highest (11.247 $\left.\mathrm{g} \mathrm{L}^{-1}\right)$ for $200 \mathrm{~mL}$ of the optimized MMRS medium, and increasing the volume slightly decreased the $\beta$-galactosidase activity (grey color, Fig. 3), in agreement with experimental values for the viable cell counts and enzymatic activity (Fig. 2, previous section). Similarly, the biomass yield on substrate consumed $\left(\mathrm{Y}_{\mathrm{X} / \mathrm{S}}\right)$ was different for the three fermentative processes for both models, and it was highest in $200 \mathrm{~mL}$ of optimized MMRS medium (0.999 and $0.974 \mathrm{~g} \mathrm{~g}^{-1}$, for the Logistic and Contois, respectively). Regarding the other culture medium volumes, the Contois model presented the lowest $Y_{X / S}\left(0.881\right.$ and $0.776 \mathrm{~g} \mathrm{~g}^{-1}$, in 800 and 3,200 mL, respectively) due to the excess of substrate present in the time considered for modeling ( $48 \mathrm{~h}$ ).

The $\mathrm{K}_{\mathrm{s}}$ values provided by the Contois model suggested that $L$. reuteri started the stationary growth phase when the substrate (lactose) concentrations were $1.225,3.510$ and $6.521 \mathrm{~g} \mathrm{~L}^{-1}$ for 200, 800 and 3,200 mL, respectively (Table 4). However, based on the experimental data (Fig. 2 lactose concentration, blue dots), the stationary growth phase was observed from $48 \mathrm{~h}$, with the residual lactose concentrations of $0.4 \mathrm{~g} \mathrm{~L}^{-1}$ for 200 and $3,200 \mathrm{~mL}$ and $0.8 \mathrm{~g} \mathrm{~L}^{-1}$ for $800 \mathrm{~mL}$. Even though both models are statistically equivalent, the Logistic model is the most adequate in terms of biomass production and substrate consumption, since the Contois model overestimated $\mathrm{K}_{\mathrm{s}}$ values.

The $\alpha$ values were found to be much higher than the $\beta$ values for both models (CbMLP and LbMLP). This fact is related to the low expression and/or loss of $\beta$-galactosidase activity during the stationary and decline growth phases. Therefore, the $\alpha$ values might indicate that $\beta$ galactosidase production is associated with $L$. reuteri growth, as mentioned in the previous section. Abbasalizadeh et al. (2015) [58] reported the same behavior when producing $\beta$-galactosidase from L. bulgaricus in culture medium with skimmed milk.

The evaluated models were based on a single substrate, and the additional carbon source (present in the casein and inactive beer yeast) may have affected some of these parameters, such as $\alpha$ and $\beta$ (see equation A.3 in the Appendix). The consequence is a mismatch between some of the experimental and predicted values, as can be seen mainly for the biomass production (black color, Fig. 3), where the model underestimated the value observed experimentally. Nevertheless, the parameters within the model compensate the additional carbon source in the culture medium, and the $\beta$-galactosidase activity predicted by the model agrees with the experimental data. Therefore, the robustness of the single substrate Logistic model provides a good fit for modeling biomass production, biomass yield on substrate consumed, and as input parameters for the modified Luedeking-Piret for $\beta$-galactosidase activity. 
Table 4. Unstructured model parameters evaluated for biomass and $\beta$-galactosidase production by Lactobacillus reuteri B-14171.

\begin{tabular}{|c|c|c|c|c|c|c|}
\hline \multirow[b]{3}{*}{$\begin{array}{l}\text { Culture medium volume } \\
(\mathbf{m L})\end{array}$} & \multicolumn{6}{|c|}{ Models } \\
\hline & \multicolumn{3}{|c|}{ Logistic } & \multicolumn{3}{|c|}{ Contois } \\
\hline & 200 & 800 & 3,200 & 200 & 800 & 3,200 \\
\hline$\mu_{\max }\left(h^{-1}\right)$ & $0.207 \pm 0.00$ & $0.234 \pm 0.00$ & $0.281 \pm 0.00$ & $0.211 \pm 0.00$ & $0.300 \pm 0.00$ & $0.407 \pm 0.00$ \\
\hline$\dot{X}_{\max }\left(g L^{-1}\right)$ & $11.247 \pm 0.11$ & $9.000 \pm 0.11$ & $9.000 \pm 0.09$ & - & - & - \\
\hline Biomass $\mathbf{R}^{2}$ & 0.940 & 0.934 & 0.884 & 0.945 & 0.948 & 0.957 \\
\hline$Y_{X / S}\left(g^{-1}\right)$ & $0.999 \pm 0.01$ & $0.838 \pm 0.01$ & $0.889 \pm 0.01$ & $0.974 \pm 0.01$ & $0.881 \pm 0.01$ & $0.776 \pm 0.01$ \\
\hline $\mathbf{K}_{\mathrm{s}}$ & - & - & - & $1.225 \pm 0.01$ & $3.510 \pm 0.04$ & $6.521 \pm 0.08$ \\
\hline \multirow[t]{2}{*}{ Substrate $\mathbf{R}^{2}$} & 0.991 & 0.982 & 0.953 & 0.990 & 0.983 & 0.971 \\
\hline & \multicolumn{3}{|c|}{ Logistic-based Modified Luedeking-Piret (LbMLP) } & \multicolumn{3}{|c|}{ Contois-based Modified Luedeking-Piret (CbMLP) } \\
\hline$\alpha$ & $0.355 \pm 0.08$ & $0.558 \pm 0.06$ & $0.408 \pm 0.01$ & $0.370 \pm 0.01$ & $0.619 \pm 0.06$ & $0.554 \pm 0.11$ \\
\hline $\boldsymbol{\beta}$ & $0.011 \pm 0.00$ & $0.006 \pm 0.00$ & $0.010 \pm 0.00$ & $0.010 \pm 0.00$ & $0.001 \pm 0.00$ & $0.007 \pm 0.00$ \\
\hline Product $\mathbf{R}^{2}$ & 0.975 & 0.977 & 0.968 & 0.974 & 0.971 & 0.961 \\
\hline
\end{tabular}

Data expressed as mean \pm sd. 


\subsection{Bioprocess parameters evaluated in the production of $\beta$-galactosidase}

Other yield coefficients are essential to evaluate the feasibility of the production process, such as the product formation yield on substrate consumed ( $\left.\mathrm{Y}_{\mathrm{P} / \mathrm{S}}\right)$ and product formation yield on biomass $\left(\mathrm{Y}_{\mathrm{P} / \mathrm{X}}\right)$. These parameters were calculated based on the experimental data and then compared to different culture medium volumes (Table 5).

Throughout the conversion of the substrate (lactose) into the product (enzymatic activity), the highest values for $\mathrm{Y}_{\mathrm{P} / \mathrm{s}}$ were observed for 200 and $800 \mathrm{~mL}$ of optimized MMRS (491.328 and $439.176 \mathrm{U} \mathrm{g} \mathrm{g}^{-1}$, respectively). A study carried out by Tari et al. (2009) [39] evaluated the production of $\beta$-galactosidase in the culture medium containing skimmed milk and corn steep liquor with an associative growth culture of lactic acid bacteria (Lactobacillus delbrueckii ssp. bulgaricus and Streptococcus thermophilus). They reported $\mathrm{Y}_{\mathrm{P} / \mathrm{S}}$ values of approximately $56.25 \mathrm{U} \mathrm{g}^{-1}$ and total productivity of $226 \mathrm{U} \mathrm{L}^{-1} \mathrm{~h}^{-1}$. The values found for $\mathrm{Y}_{\mathrm{P} / \mathrm{S}}$ in our study were seven-fold higher (434.063 $\mathrm{U} \mathrm{g}^{-1}$ on average), with the total productivity four-fold lower (on average $86 \mathrm{U} \mathrm{L}^{-1} \mathrm{~h}^{-1}$, Table 5) compared to the study mentioned above. The variations in the bioprocess parameters ( $\mathrm{Y}_{\mathrm{P} / \mathrm{S}}, \mathrm{Y}_{\mathrm{P} / \mathrm{X}}$, $\mathrm{P}_{\mathrm{p}}$, and $\mathrm{P}_{\mathrm{m}}$ ) can be explained by the lactic acid bacteria that were used and also by the difference in the composition of the culture medium since lactic acid bacteria present different nutritional requirements even among the same genus [59].

The long fermentation time and the conditions of submerged fermentation influence the efficiency of the bioprocess, especially when the focus is scaling-up. Consequently, the product formation yield might be affected by the culture medium volume increase. In fact, when the culture medium volume increased from $200 \mathrm{~mL}$ to $3,200 \mathrm{~mL}$, it was observed a reduction in product formation yield on substrate conversion ( $\mathrm{Y}_{\mathrm{P} / \mathrm{S}}$, reduction of $24 \%$, with a significant difference) and on biomass ( $\mathrm{Y}_{\mathrm{P} / \mathrm{X}}$, reduction of $19 \%$, with no significant difference), affecting total and maximum productivities $\left(\mathrm{P}_{\mathrm{p}}\right.$ and $\mathrm{P}_{\mathrm{m}}$, respectively). These reductions may have been influenced by the cell concentrations, which are also affected by the culture medium volume (see section "Effect of different volumes of the culture medium on $\beta$-galactosidase activity"). As a result, the observed decrease in biomass concentration for $3,200 \mathrm{~mL}$ may affect the product formation and the yield factors.

We have shown in this work that Lactobacillus reuteri B-14171 has a great ability to produce $\beta$-galactosidase, and the use of cheap nitrogen sources proved to have satisfactory results in terms of productivity and yield factors. However, our experimental set-up has some limitations that need to be further improved, such as the mass transfer deficiency caused using Erlenmeyer flasks since the fermentation process occurred in microaerophilic static conditions. These limitations might also contribute to the reductions in yield factors and the productivities, as shown in Table 5. Therefore, future studies regarding the scale-up process of $\beta$-galactosidase production by Lactobacillus reuteri in this culture medium may be performed at a bioreactor level where mixing characteristics, aeration rate, and dissolved carbon dioxide during the fermentation process can be measured and better controlled.

Table 5. Bioprocess parameters evaluated in the production of $\beta$-galactosidase by Lactobacillus reuteri B14171 in 200; 800 and 3,200 mL MMRS medium in SmF at $37^{\circ} \mathrm{C}$ for $56 \mathrm{~h}$.

\begin{tabular}{ccccc}
\hline \multicolumn{4}{c}{ Parameters } \\
\hline $\begin{array}{c}\text { Culture medium } \\
\text { volume }(\mathbf{m L})\end{array}$ & $\mathbf{Y}_{\mathbf{P} / \mathbf{S}}\left(\mathbf{U ~ g}^{-1}\right)^{*}$ & $\mathbf{Y}_{\mathbf{P} / \mathbf{X}}\left(\mathbf{U ~ g}^{-1}\right)^{*}$ & $\mathbf{P}_{\mathbf{p}}\left(\mathbf{U ~ L ~}^{-1} \mathbf{h}^{-1}\right)^{*}$ & $\mathbf{P}_{\mathbf{m}}\left(\mathbf{U ~ L}^{-1} \mathbf{h}^{-1}\right)^{*}$ \\
\hline $\mathbf{2 0 0}$ & $491.328^{\mathrm{a}}$ & $504.081^{\mathrm{a}}$ & $97.810^{\mathrm{a}}$ & $145.943^{\mathrm{a}}$ \\
$\mathbf{8 0 0}$ & $439.176^{\mathrm{a}, \mathrm{b}}$ & $446.541^{\mathrm{a}}$ & $85.082^{\mathrm{a}}$ & $133.271^{\mathrm{a}}$ \\
$\mathbf{3 , 2 0 0}$ & $371.684^{\mathrm{b}}$ & $407.870^{\mathrm{a}}$ & $73.992^{\mathrm{a}}$ & $125.006^{\mathrm{a}}$ \\
\hline
\end{tabular}

$\mathrm{Y}_{\mathrm{P} / \mathrm{S}}$ : product formation yield on substrate consumed; $\mathrm{Y}_{\mathrm{P} / \mathrm{X}}$ : product formation yield on biomass; $\mathrm{P}_{\mathrm{P}}$ : total productivity; $\mathrm{P}_{\mathrm{m}}$ : maximum productivity.

Different letters in the same column represent mean values with significant difference $(p \leq 0.05)$, and the same letters represent mean values without significant difference $(p>0.05)$.

*Enzymatic activity was expressed in $\mathrm{U} \mathrm{L}^{-1}$. 


\section{CONCLUSION}

There is a demand for low-cost nitrogen sources in microbial enzymatic production. In this work, $\beta$-galactosidase production by Lactobacillus reuteri B-14171, using casein and inactive beer yeast, is reported. The optimized MMRS medium achieved an enzymatic activity of $7.28 \mathrm{U} \mathrm{mL}^{-1}$. This medium was evaluated for process feasibility on three different culture medium volumes, and mathematical models were applied to predict the experimental data. Even though a slight reduction in enzymatic levels was observed when the culture medium volume increased, the bioprocess productivity and yield factors were not significantly affected. The Logistic model provided a good agreement regarding biomass production and substrate consumption. The modified LuedekingPiret model was suitable for predicting $\beta$-galactosidase activity for three different volumes of culture medium. These results demonstrate that the enzymatic production is growth-associated. The potential of scaling-up the $\beta$-galactosidase production using $L$. reuteri B-14171 in submerged fermentation is justified by the evaluated bioprocess parameters in this work.

\section{FUNDING}

This study was financed in part by the Coordination for the Improvement of Personnel in Higher Level - CAPES - Finance Code 001; the National Council for Scientific and Technological Development - CNPq under grant (number 310424/2015-1; \#303789/2016-6); and the Araucaria Foundation - AF under grant (number 06/2017 - 47395).

\section{REFERENCES}

1. Saqib S, Akram A, Halim SA, Tassaduq R. Sources of $\beta$-galactosidase and its applications in food industry. 3 Biotech. 2017;7(1):1-7, doi: 10.1007/s13205-017-0645-5

2. Zolnere K, Ciprovica I. The comparison of commercially available $\beta$-galactosidases for dairy industry: review. Res Rural Dev. International Scientific Conference Proceedings (Latvia). 2017;1:215-22, doi: 10.22616/rrd.23.2017.032

3. Lu L, Guo L, Wang K, Liu Y, Xiao M. $\beta$-Galactosidases: a great tool for synthesizing galactosecontaining carbohydrates. Biotechnol Adv. 2019;39:1-15, doi: 10.1016/j.biotechadv.2019.107465

4. Martarello RD, Cunha L, Cardoso SL, de Freitas MM, Silveira D, Fonseca-Bazzo YM, et al. Optimization and partial purification of beta-galactosidase production by Aspergillus niger isolated from Brazilian soils using soybean residue. AMB Express. 2019;9:81-93, doi: 10.1186/s13568-019-0805-6

5. Persistence Market Research. Global market study on lactase: growing consumption of lactase in pharmaceuticals to provide market players with lucrative prospects [Internet]. Mar 2018 [cited 2020 Oct 25]. Available from: https://www.persistencemarketresearch.com/market-research/lactase-market.asp

6. Gänzle MG, Haase G, Jelen P. Lactose: Crystallization, hydrolysis and value-added derivatives. Int Dairy J. 2008;18(7):685-94, doi: 10.1016/j.idairyj.2008.03.003

7. Akcan N. High level production of extracellular $\beta$-galactosidase from Bacillus licheniformis ATCC 12759 in submerged fermentation. African J Microbiol Res. 2011;5(26):4615-21, doi: 10.5897/AJMR11.716

8. Manera AP, Ores JDC, Ribeiro VA, Rodrigues MI, Kalil SJ, Maugeri Filho F. Use of agroindutrial residues in biotechnological process by Beta-galactosidase production from Kluyveromyces marxianus CCT 7082. Acta Sci Technol. 2011;33(2):155-61, doi: 10.4025/actascitechnol.v33i2.9919

9. Kazemi S, Khayati G, Faezi-Ghasemi M. $\beta$-galactosidase production by Aspergillus niger ATCC 9142 using inexpensive substrates in solid-state fermentation: optimization by orthogonal arrays design. Iran Biomed J. 2016;20(5):287-94, doi: 10.22045/ibj.2016.06

10. Silvério SC, Macedo EA, Teixeira JA, Rodrigues LR. New B-galactosidase producers with potential for prebiotic synthesis. Bioresour Technol. 2018;250:131-9, doi: 10.1016/j.biortech.2017.11.045

11. Carevic M, Vukasinovic-Sekulic M, Grbavcic S, Stojanovic M, Mihailovic M, Dimitrijevic A, et al. Optimization of $\beta$-galactosidase production from lactic acid bacteria. Hem Ind. 2015;69(3):305-12, doi: 10.2298/HEMIND140303044C

12. Carevic M, Vukasinovic-Sekulic M, Corovic M, Rogniaux H, Ropartz D, Velicković D, et al. Evaluation of $\beta$-galactosidase from Lactobacillus acidophilus as biocatalyst for galacto-oligosaccharides synthesis: Product structural characterization and enzyme immobilization. J Biosci Bioeng. 2018;126(6):697-704, doi: 10.1016/j.jbiosc.2018.06.003 
13. Gomaa EZ. $\beta$-galactosidase from Lactobacillus delbrueckii and Lactobacillus reuteri: optimization, characterization and formation of galactooligosaccharides. Indian J Biotechnol. 2018;17:407-15

14. Gomes TA, Spier MR, Vaz M. Microbial Beta-galactosidase: production, bioprocess parameters and downstream. In: Kras E, editor. Beta-galactosidase: properties, structure and functions. New York (US): Nova Science Publishers; 2019. p. 1-20.

15. Kittibunchakul S, van Leeuwen SS, Dijkhuizen L, Haltrich D, Nguyen T-H. Structural comparison of different galacto-oligosaccharides mixtures formed by $\beta$-galactosidases from lactic acid bacteria and bifidobacteria. J Agric Food Chem. 2020;68(15):4437-46, doi: 10.1021/acs.jafc.9b08156

16. Hidalgo-Morales M, Robles-Olvera V, Garcia HS. Lactobacillus reuteri beta-galactosidase activity and low milk acidification ability. Can J Microbiol. 2005;51(3):261-7, doi: 10.1139/w04-134

17. Mu Q, Tavella VJ, Luo XM. Role of Lactobacillus reuteri in human health and diseases. Front Microbiol. 2018;9:757, doi: 10.3389/fmicb.2018.00757

18. Singh TP, Kaur G, Malik RK, Schillinger U, Guigas C, Kapila S. Characterization of intestinal Lactobacillus reuteri strains as potential probiotics. Probiotics Antimicrob Proteins. 2012;4(1):47-58, doi: 10.1007/s12602-012-9090-2

19. Navarro JB, Mashburn-Warren L, Bakaletz LO, Bailey MT, Goodman SD. Enhanced probiotic potential of Lactobacillus reuteri when delivered as a biofilm on dextranomer microspheres that contain beneficial cargo. Front Microbiol. 2017;8:489, doi: 10.3389/fmicb.2017.00489

20. He B, Hoang TK, Tian X, Taylor CM, Blanchard E, Luo M, et al. Lactobacillus reuteri reduces the severity of experimental autoimmune encephalomyelitis in mice by modulating gut microbiota. Front Immunol. 2019;10:385, doi: 10.3389/fimmu.2019.00385

21. Nguyen T, Splechtna B, Steinböck M, Kneifel W, Lettner HP, Kulbe KD, et al. Purification and characterization of two novel $\beta$-galactosidases from Lactobacillus reuteri. J Agric Food Chem. 2006;54(14):4989-98, doi: 10.1021/jf053126u

22. Ibrahim SA, Alazzeh AY, Awaisheh SS, Song D, Shahbazi A, AbuGhazaleh AA. Enhancement of $\alpha$ - and $\beta$-galactosidase activity in Lactobacillus reuteri by different metal ions. Biol Trace Elem Res. 2010;136(1):106-16, doi: 10.1007/s12011-009-8519-2

23. Carevic M, Banjanac K, Corovic M, Jakovetic S, Milivojevic A, Vukasinovic M, et al. Selection of lactic acid bacteria strain for simultaneous production of $\alpha$ - and $\beta$-galactosidases. Zast Mater. 2016;57(2):26573, doi: 10.5937/ZasMat1602265c

24. Zhang D, Ji H, Liu H, Wang S, Wang J, Wang Y. Complete genome sequence of probiotic Lactobacillus reuteri ZLR003 isolated from healthy weaned pig. J Biotechnol. 2016;228:69-70, doi: 10.1016/j.jbiotec.2016.04.044

25. Gomes TA, Santos LB, Nogueira A, Spier MR. Increase in an intracellular $\beta$-galactosidase biosynthesis using L. reuteri NRRL B-14171, inducers and alternative low-cost nitrogen sources under submerged cultivation. Int J Food Eng. 2018;14:1-12, doi: 10.1515/ijfe-2017-0333

26. Li M, Zhu H, Qin H, Zhang Y, Yang H. Optimization of a whey containing medium for $\beta$-galactosidase production by Lactobacillus reuteri. In: Zhang T-C, Nakajima M, editors. Advances in applied Biotechnology. Berlin (DE): Springer Berlin Heidelberg; 2015. p. 599-608.

27. Ayad AA, Gad El-Rab DA, Ibrahim SA, Williams LL. Nitrogen sources effect on Lactobacillus reuteri growth and performance cultivated in date palm (Phoenix dactylifera L.) by-products. Fermentation. 2020;6(3):64, doi: 10.3390/fermentation6030064

28. Monod J. The growth of bacterial cultures. Annu Rev Microbiol. 1949;3:371-94, doi: 10.1146/annurev.mi.03.100149.002103

29. Kumar A, Kumar S, Kumar S. Biodegradation kinetics of phenol and catechol using Pseudomonas putida MTCC 1194. Biochem Eng J. 2005;22(2):151-9, doi: 10.1016/j.bej.2004.09.006

30. Contois DE. Kinetics of bacterial growth: relationship between population density and specific growth rate of continuous cultures. J Gen Microbiol. 1959;21:40-50, doi: 10.1099/00221287-21-1-40

31. Luedeking R, Piret EL. A kinetic study of the lactic acid fermentation. Batch process at controlled $\mathrm{pH}$. J Biochem Microbiol Technol Eng. 1959;1(4):393-412, doi: 10.1002/jbmte.390010406

32. Gomes TA, Zanette CM, Spier MR. An overview of cell disruption methods for intracellular biomolecules recovery. Prep Biochem Biotechnol. 2020;50(7):635-54, doi: 10.1080/10826068.2020.1728696

33. Food Chemical Codex. Lactase (neutral) $\beta$-galactosidase activity. Food Chemical Codex. 7 th ed. Washington (US): National Academy Press; 2004. p. 911-3.

34. Choonia HS, Lele SS. $\beta$-Galactosidase release kinetics during ultrasonic disruption of Lactobacillus acidophilus isolated from fermented Eleusine coracana. Food Bioprod Process. 2011;89(4):288-93, doi: 10.1016/j.fbp.2010.08.009

35. Sanada CTN, Karp SG, Spier MR, Portella AC, Gouvêa PM, Yamaguishi CT, et al. Utilization of soybean vinasse for $\alpha$-galactosidase production. Food Res Int. 2009;42(4):476-83, doi: 10.1016/j.foodres.2009.01.017 
36. Pirisino JF. High performance liquid chromatographic determination of lactose, glucose, and galactose in lactose-reduced milk. J Food Sci. 1983;48:742-4, doi: 10.1111/j.1365-2621.1983.tb14887.x

37. Vasiljevic T, Jelen P. Production of $\beta$-galactosidase for lactose hydrolysis in milk and dairy products using thermophilic lactic acid bacteria. Innov Food Sci Emerg Technol. 2001;2(2):75-85, doi: 10.1016/S1466-8564(01)00027-3

38. Dagbagli S, Goksungur Y. Optimization of beta-galactosidase production using Kluyveromyces lactis NRRL Y-8279 by response surface methodology. Electron J Biotechnol. 2008;11(4):1-12, doi: $10.4067 /$ S0717-34582008000400011

39. Tari C, Ustok FI, Harsa S. Optimization of the associative growth of novel yoghurt cultures in the production of biomass, $\beta$-galactosidase and lactic acid using response surface methodology. Int Dairy J. 2009;19(4):236-43, doi: 10.1016/J.IDAIRYJ.2008.10.009

40. Selvarajan E, Mohanasrinivasan V. Kinetic studies on exploring lactose hydrolysis potential of $\beta$ galactosidase extracted from Lactobacillus plantarum HF571129. J Food Sci Technol. 2015;52(10):620617, doi: 10.1007/s13197-015-1729-z

41. Hsu CA, Yu RC, Chou CC. Production of $\beta$-galactosidase by Bifidobacteria as influenced by various culture conditions. Int J Food Microbiol. 2005;104(2):197-206, doi: 10.1016/j.ijfoodmicro.2005.02.010

42. Prasad LN, Ghosh BC, Sherkat F, Shah N. Extraction and characterisation of $\beta$-galactosidase produced by Bifidobacterium animalis spp. lactis Bb12 and Lactobacillus delbrueckii spp. bulgaricus ATCC 11842 grown in whey. Int Food Res J. 2013;20(1):487-94.

43. Leong-Morgenthaler P, Zwahlen MC, Hottinger H. Lactose metabolism in Lactobacillus bulgaricus: analysis of the primary structure and expression of the genes involved. J Bacteriol. 1991;173(6):1951-7, doi: 10.1128/jb.173.6.1951-1957.1991

44. Nath A, Mondal S, Chakraborty S, Bhattacharjee C, Chowdhury R. Production, purification, characterization, immobilization, and application of $\beta$-galactosidase: A review. Asia-Pacific J Chem Eng. 2014;9:330-48, doi: 10.1002/apj.1801

45. Iskandar CF, Cailliez-Grimal C, Borges F, Revol-Junelles AM. Review of lactose and galactose metabolism in Lactic Acid Bacteria dedicated to expert genomic annotation. Trends Food Sci Technol. 2019;88:121-32, doi: 10.1016/j.tifs.2019.03.020

46. Sahoo TK, Jayaraman G. Co-culture of Lactobacillus delbrueckii and engineered Lactococcus lactis enhances stoichiometric yield of d-lactic acid from whey permeate. Appl Microbiol Biotechnol. 2019;103(14):5653-62, doi: 10.1007/s00253-019-09819-7

47. Nguyen T-T, Nguyen HA, Arreola SL, Mlynek G, Djinovic-Carugo K, Mathiesen G, et al. Homodimeric beta-galactosidase from Lactobacillus delbrueckii subsp. bulgaricus DSM 20081: expression in Lactobacillus plantarum and biochemical characterization. J Agric Food Chem. 2012;60(7):1713-21, doi: $10.1021 / \mathrm{jf} 203909 \mathrm{e}$

48. Kamran A, Bibi Z, Aman A, Qader SAU. Lactose hydrolysis approach: isolation and production of $\beta$ galactosidase from newly isolated Bacillus strain B-2. Biocatal Agric Biotechnol. 2016;5:99-103, doi: 10.1016/j.bcab.2015.12.010

49. Alikkunju AP, Sainjan N, Silvester R, Joseph A, Rahiman M, Antony AC, et al. Screening and characterization of cold-active $\beta$-Galactosidase producing psychrotrophic Enterobacter ludwigii from the sediments of Arctic fjord. Appl Biochem Biotechnol. 2016;180(3):477-90, doi: 10.1007/s12010-0162111-y

50. Jing H, Kitts DD. Chemical and biochemical properties of casein-sugar Maillard reaction products. Food Chem Toxicol. 2002;40(7):1007-15, doi: 10.1016/S0278-6915(02)00070-4

51. Helou C, Marier D, Jacolot P, Abdennebi-Najar L, Niquet-Léridon C, Tessier FJ, et al. Microorganisms and Maillard reaction products: a review of the literature and recent findings. Amino Acids. 2014;46:26777, doi: 10.1007/s00726-013-1496-y

52. Mobayed FH, Nunes JC, Gennari A, de Andrade BC, Ferreira MLV, Pauli P, et al. Effect of by-products from the dairy industry as alternative inducers of recombinant $\beta$-galactosidase expression. Biotechnol Lett. 2021;43(3):589-99, doi: 10.1007/s10529-020-03028-3

53. Zhang S, Xu Z, Qin L, Kong J. Development of strong lactose/galactose-inducible expression system for Lactobacillus plantarum by optimizing promoter. Biochem Eng J. 2019;151:107316, doi: 10.1016/j.bej.2019.107316

54. Von Wright A, Axelsson L. Lactic acid bacteria: an introduction. In: Lahtinen S, Ouwehand AC, Salminen S, Von Wright A, editors. Lactic acid bacteria: microbiological and functional aspects. London (UK): CRC Press; 2011. p. 1-17, doi: 10.1201/b11503

55. Boze H, Moulin G, Galzy P. Production of food and fodder yeasts. Crit Rev Biotechnol. 1992;12(1-2):6586, doi: $10.3109 / 07388559209069188$ 
56. Hall WL, Millward DJ, Long SJ, Morgan LM. Casein and whey exert different effects on plasma amino acid profiles, gastrointestinal hormone secretion and appetite. Br J Nutr. 2003;89(2):239-48, doi: 10.1079/BJN2002760

57. Roelfs M, Kroon PC. Symfit 0.3.7 2019, doi: 10.5281/zenodo.1133336

58. Abbasalizadeh S, Hejazi MA, Hajiabbas MP. Kinetics of $\beta$-galactosidase production by Lactobacillus bulgaricus during $\mathrm{pH}$ controlled batch fermentation in three commercial bulk starter media. Appl Food Biotechnol. 2015;2(4):39-47, doi: 10.22037/afb.v2i4.9512

59. Hayek SA, Ibrahim SA. Current limitations and challenges with lactic acid bacteria: a review. Food Nutr Sci. 2013;4(11):73-87, doi: 10.4236/fns.2013.411A010

\section{APPENDIX}

\section{Mathematical modeling background}

The Logistic model [29] was used by the authors in the degradation of phenol and catechol by Pseudomonas putida; this is a simplified, unstructured model which is considered to be kinetic. In this model, the specific microbial growth rate is:

$$
\mu=\mu_{\max }\left(1-\frac{X}{X_{\max }}\right)
$$

where $\mu_{\max }$ is the maximum specific growth rate $\left(\mathrm{h}^{-1}\right), \mathrm{X}$ is the biomass concentration $\left(\mathrm{g} \mathrm{L}^{-1}\right)$, and $\mathrm{X}_{\max }$ is the maximum biomass concentration $\left(\mathrm{g} \mathrm{L}^{-1}\right)$.

Contois (1959) [30] developed a model in which the half-saturation rate is assumed to be dependent on the biomass concentration, as well as the nutrient concentration (substrate, $\mathrm{S}, \mathrm{g} \mathrm{L}^{-1}$ ). In this model, $\mu_{\max }$ and $\mathrm{B}$ are constant growth parameters under defined culture conditions. The Contois model can be expressed as follows:

$$
\mu=\frac{\mu_{\max } S}{B X+S}
$$

The kinetic model proposed by Luedeking and Piret (1959) [31] has been widely used to describe the relationship between cell growth and product formation. Consequently, this model was applied to the $\beta$-galactosidase activity, based on the parameters evaluated using the Logistic and Contois models. In this study, the original equation of the Luedeking-Piret model was modified, inserting the relative increase in the product formation rate (P, $\beta$-galactosidase, Eq. A.3), aiming for the best adjustment of the model to the observed peak enzymatic activity. For the application of the modified Luedeking-Piret model, the product formation was considered only until the peak of $\beta$-galactosidase activity is reached. Thus, the equation describing the model was defined as follows:

$$
\frac{d P}{d t}=\left(\alpha \frac{d X}{d t}+\beta X\right) P
$$

The $\alpha$ and $\beta$ coefficients are empirical constants, which are dependent and non-dependent on microbial growth, respectively. These empirical constants vary according to the microbial strain, culture medium and fermentation conditions [31]. The term $\alpha \mathrm{dX} / \mathrm{dt}$ refers to the product formation rate associated with cell growth, and it describes the additional product formation by microbial growth. The term $\beta \mathrm{X}$ describes the product formation rate associated with non-growth conditions. The term $\mathrm{X}$ represents the total biomass values and $\mathrm{P}$ represents $\beta$-galactosidase activity $\left(\mathrm{U} \mathrm{mL}^{-1}\right)$, both determined up to the peak of maximum activity. For both models (Logistic and Contois) the biomass yield on substrate consumed $\left(\mathrm{Y}_{\mathrm{X} / \mathrm{S}}\right)$ was determined based on the variation of substrate concentration (lactose, $\mathrm{g} \mathrm{L}^{-1}$ ) over the growing time (dS/dt), and was expressed by the following equation:

$$
\frac{d S}{d t}=\frac{-d X}{d t} \frac{1}{Y_{X / S}}
$$

